\title{
Identification of column-integrated dominant aerosols using the archive of AERONET data set
}

Y. Choi ${ }^{1}$, Y. S. Ghim ${ }^{1}$, and B. N. Holben ${ }^{2}$

${ }^{1}$ Department of Environmental Science, Hankuk University of Foreign Studies, Yongin, 449-791, Korea

${ }^{2}$ NASA Goddard Space Flight Center, Greenbelt, MD, USA

Received: 19 August 2013 - Accepted: 30 September 2013 - Published: 15 October 2013

Correspondence to: Y. S. Ghim (ysghim @ hufs.ac.kr)

Published by Copernicus Publications on behalf of the European Geosciences Union.

Identification of column-integrated dominant aerosols

Y. Choi et al.

\section{Title Page}

\section{Full Screen / Esc}

Printer-friendly Version

Interactive Discussion 


\section{Abstract}

Dominant aerosols were distinguished from level 2 inversion products for the Anmyon Aerosol Robotic Network (AERONET) site between 1999 and 2007. Secondary inorganic ions, black carbon $(\mathrm{BC})$ and organic carbon $(\mathrm{OC})$ were separated from fine mode 5 aerosols, and mineral dust (MD), MD mixed with carbon, mixed coarse particles were separated from coarse mode aerosols. Four parameters (aerosol optical depth, single scattering albedo, absorption Angstrom exponent, and fine mode fraction) were used for this classification. Monthly variation of the occurrence rate of each aerosol type reveals that MD and MD mixed with carbon are frequent in spring. Although the fracilon anong dominant aerosols and occurrence rates of $B C$ and $O C$ tend to be high in cold season for heating, their contributions are variable but consistent due to various combustion sources. Secondary inorganic ions are most prevalent from June to August; the effective radius of these fine mode aerosols increases with water vapor content because of hygroscopic growth. To evaluate the validity of aerosol types identified, dominant aerosols at worldwide AERONET sites (Beijing, Mexico City, Goddard Space Flight Center, Mongu, Alta Floresta, Cape Verde), which have distinct source characteristics, were classified into the same aerosol types. The occurrence rate and fraction of the aerosol types at the selected sites confirm that the classification in this study is reasonable. However, mean optical properties of the aerosol types are generally influenced by the aerosol types with large fractions. The present work shows that the identification of dominant aerosols is effective even at a single site, provided that the archive of the data set is properly available.

\section{Introduction}

Although uncertainties in the effects of aerosols on climate change have been reduced through the 4th assessment report (IPCC, 2007), scientific understanding of aerosols is still much low compared with long-lived greenhouse gases such as $\mathrm{CO}_{2}$ and $\mathrm{CH}_{4}$.
ACPD

13, 26627-26656, 2013

Identification of column-integrated dominant aerosols

Y. Choi et al.

Title Page 
Major difficulties in dealing with aerosols occur due to large spatial and temporal variations resulting from their shorter residence time. These difficulties are compounded by maldistribution of information on aerosols, both spatially and temporally. With growing interest on aerosols, ground-based optical measurements from networks, such as 5 AERONET (AErosol Robotic Network; Holben et al., 2001), SKYNET (SKYradiometer Network; Takamura et al., 2004), and GAWPFR (Global Atmosphere Watch Precision Filter Radiometers) network (WMO, 2005) have become the subject of many studies. At first these networks were developed to compare and validate satellite observations (Holben et al., 2001). However, as the number of measurement sites increases, many 10 advantages of ground-based measurements have been acknowledged. They can provide information steadily at fixed locations and their coverage now extends to almost every part of the world, with an ever increasing number of sites. Furthermore, optical measurements of column aerosols have merits over physical and chemical measurements of surface aerosols. They include that column data are more useful in estimating 15 the radiative forcing, and that optical measurements require less labor and expense than intricate physical and chemical measurements.

One of the promising research subjects using data from ground-based optical measurement networks is the identification of dominant aerosols at a specific site or region. This kind of information has been available only from long-term measurements of the speciated aerosol data, which are implemented in selected areas of the United States and Europe. On the other hand, Omar et al. (2005) classified dominant aerosols in the world from the archive of the AERONET data set. They identified six types of aerosols representing desert dust, biomass burning, urban industrial pollution, rural background, polluted marine, and dirty pollution, using 26 parameters, including optical properties such as single scattering albedo (SSA) and complex refractive indices.

Table 1 summarizes several works classifying dominant aerosol types using optical properties. Russell et al. (2010) distinguished urban-industrial, biomass burning, and desert dust aerosols using Angstrom exponent (AE) and absorption AE (AAE). Their work results from many studies investigating the differences in spectral dependency

\section{ACPD}

13, 26627-26656, 2013

Identification of column-integrated dominant aerosols

Y. Choi et al.

Title Page

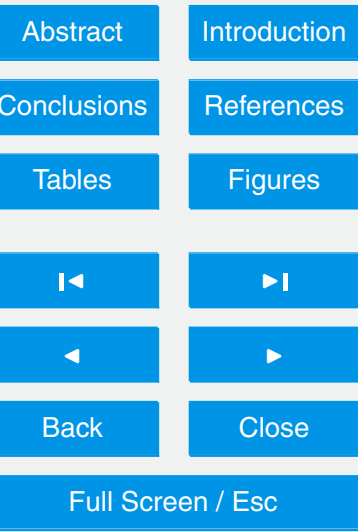

Printer-friendly Version

Interactive Discussion 
of absorption between black carbon (BC), organic carbon (OC), and desert dust (Eck et al., 1999; Bergstrom et al., 2004, 2007). The work of Russell et al. (2010) was elaborated by Giles et al. (2012) using two more parameters of SSA and fine-mode fraction (FMF), and introducing the mixtures of absorbing aerosols. Recently Logan 5 et al. (2013) introduced single scattering co-albedo (1-SSA) to classify absorption aerosols at four AERONET sites in East Asia.

Lee et al. (2010) classified aerosol types into coarse-mode dust and fine-mode nonabsorbing and absorbing aerosols using FMF and SSA. This approach is noteworthy from the standpoints that four groups were divided with two basic parameters and that 10 only distinct types were identified by designating intermediate groups as uncertain and mixture ones. Estimation of the four aerosol groups of dust, sea salt, carbonaceous materials and sulfate, considering fine and coarse modes and absorption and scattering is common in the analysis of satellite data (Higurashi and Nakajima, 2002; J. Kim et al., 2007). Mielonen et al. (2009) compared Cloud-Aerosol Lidar with Orthogonal Polariza15 tion (CALIOP) satellite data and AERONET data using SSA and AE, and classified six aerosol groups by allowing intermediate groups between coarse and fine aerosols and between absorbing and non-absorbing aerosols.

Yang et al. (2009) measured scattering and absorption along with chemical and physical properties including organic and elemental carbons, as well as size distributions, during the EAST-AIRE (East Asian Study of Tropospheric Aerosols: an International Regional Experiment) campaign. With these intensive measurements they were able to discriminate detailed variations in absorption properties of dominant aerosols in air masses arriving at a site. This is different from other works in Table 1 (except this study) which identified distinct aerosol types using the data set from wide areas involving various sources such as vehicles, biomass burning, marine, and desert.

We investigated dominant aerosol types at a single AERONET site of Anmyon by examining the optical properties in the archive of AERONET database between 1999 and 2007 . Anmyon site $\left(36.54^{\circ} \mathrm{N}, 126.33^{\circ} \mathrm{E}\right)$ is located on the west coast of the Korean Peninsula (Fig. 1). Although the site is regarded as a typical rural or background site
ACPD

13, 26627-26656, 2013

Identification of column-integrated dominant aerosols

Y. Choi et al.

Title Page

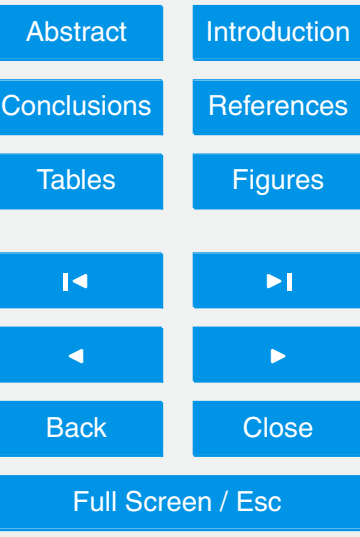

Printer-friendly Version

Interactive Discussion 
in Korea, without major sources nearby (S.-W. Kim et al., 2007), it is affected by the transport of anthropogenic pollutants from the Asian Continent associated with prevailing westerlies. As a result, the Anmyon site was classified as a polluted continental site in Omar et al. (2005) along with a large amount of fine mode aerosols and a similar 5 amount of coarse mode aerosols (Eck et al., 2005).

The dominant aerosols at a site are determined by interactions between transport and local emissions, which vary over time. In the present work, we first distinguish dominant aerosols for the Anmyon site and investigate the characteristics of these aerosol types, such as differences in optical properties and the monthly variations of

10 their occurrence rates. Next, we classify dominant aerosols at AERONET sites, having clearly different source characteristics, into the aerosol types identified for the Anmyon site, and examine the results in comparison with previous works for the same sites.

\section{Methods}

An automatic tracking sun and sky-scanning radiometer, CE 318 (CIMEL Electronique; 15 also called a sunphotometer) measures direct radiation on the principal plane (with fixed azimuth angle and varied zenith angle) and diffusive radiation on the almucantar plane (with fixed zenith angle and varied azimuth angle up to $180^{\circ}$ in both sides) at 8 wavelength channels (340, 380, 440, 500, 675, 870, 940 and $1020 \mathrm{~nm}$ ) (Holben et al., 2001). Direct radiation is measured approximately every $6 \mathrm{~min}$, and aerosol optical depth (AOD) is retrieved at all wavelengths, except at $940 \mathrm{~nm}$ which is for calculating column water vapor. Diffuse radiation is measured at optical air masses of 4, 3, 2, and 1.7 in the morning and afternoon, respectively, and once per hour in between (Eck et al., 2010). Using the measurements at 4 channels $(440,675,870,1020 \mathrm{~nm})$, volume size distribution and complex refractive indices were determined by comparing AOD

\section{ACPD}

13, 26627-26656, 2013

Identification of column-integrated dominant aerosols

Y. Choi et al.

Title Page
Abstract

Conclusions

Tables

14

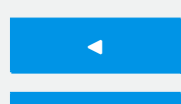

Back

\section{Introduction}

References

Figures

$>1$

Close
Full Screen / Esc

Printer-friendly Version

Interactive Discussion SSA were retrieved (Dubovik et al., 2000, 2006). 
In this work we used the level 2 product which is cloud screened and quality assured by excluding low $\mathrm{AOD}\left(\mathrm{AOD}_{440}<0.4\right)$ and low solar zenith angle $\left(\mathrm{SZA}<50^{\circ}\right)($ Smirrnov et al., 2000; Holben et al., 2006). As seen in Table 1 we adopted 4 parameters to identify aerosol characteristics. AOD represents aerosol loading in the column. SSA 5 is an indicator of aerosol scattering. Absorption AOD (AAOD) is an absorption part of AOD at each wavelength which is defined as

$\mathrm{AAOD}_{\lambda}=\left(1-\mathrm{SSA}_{\lambda}\right) \times \mathrm{AOD}_{\lambda}$

where $\lambda$ denotes wavelength. AAE is an exponent of the wavelength dependence of AAOD, that is,

$10 \mathrm{AAOD}_{\lambda}=K \lambda^{-\mathrm{AAE}}$

where $K$ is a constant.

$A E$ is a traditional indicator of dominant aerosol size in the column (Ångström, 1961). $\mathrm{AE}$ lower than 1 indicates that coarse particles are clearly dominated while $A E$ higher than 2 indicates that fine particles like products from combustion processes are prevalent (Schuster et al., 2006). However, in the intermediate range between 1 and 2, which is most frequent in atmospheric aerosols, it is not clear which size is dominant (Schuster et al., 2006; Prats et al., 2011). Therefore, we used FMF in the volume size distribution instead of $A E$ to discern the dominant size. FMF was calculated as the sum of the volume below the stationary point between fine and coarse modes, the point being in the range of $0.44-0.99 \mu \mathrm{m}$ (Schafer et al., 2008).

The following are descriptions of the classification method of dominant aerosols in the present work, shown in Fig. 2. (1) AOD less than 0.4 was excluded as "low AOD" since this AOD is too low to obtain valid optical properties to identify dominant aerosol. (2) The imaginary part of the refractive index at $440 \mathrm{~nm}$ less than the mean of the indices at 670,870 and $1020 \mathrm{~nm}$ was excluded according to Arola et al. (2011). This is because spectral dependence of the imaginary refractive index is explained by a relatively constant for $\mathrm{BC}$ and an increase with the addition of $\mathrm{OC}$ and dust (Kirchstetter 26632
ACPD

13, 26627-26656, 2013

Identification of column-integrated dominant aerosols

Y. Choi et al.

Title Page
Abstract

Conclusions

Tables

14

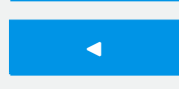

Back

\section{Introduction}

References

Figures

$>1$

$>$

Close
Full Screen / Esc

Printer-friendly Version

Interactive Discussion 
et al., 2004; Chin et al., 2009). Most of the data (91\%), which was excluded due to this restriction of the imaginary refractive index, had an AAE lower than 1. In this work, the latter was regarded as a result of error from measurement uncertainty (Bergstrom et al., 2007).

5 (3) Whether dominant aerosols are coarse or fine was determined using FMF with a threshold value of 0.5 (Eck et al., 2005, 2010; Giles et al., 2012). Dominant aerosols are coarse when FMF $\leq 0.5$ and fine otherwise. (4) Scattering aerosols were discriminated using SSA. Sea salt and secondary inorganic ions are representative scattering aerosols. SSA should be 1.0 for pure scattering aerosols, but is lowered with mixing of 10 absorption aerosols. We used a value of 0.95 for the lower limit of scattering aerosols for the fine mode, that is, we separated secondary ions such as ammonium sulfate and nitrate when $\mathrm{SSA}_{440}>0.95$. This criterion was also used by Lee et al. (2010) and Levy et al. (2007). In TARFOX (Tropical Aerosol Radiative Forcing Observational Experiment), in which concentrations of non-sea salt sulfate and ammonium were higher than other campaigns (Quinn and Bates, 2005), SSA was varied from 0.90-0.98 depending on the measurement instrument, relative humidity and altitude (Russell et al., 2002). In contrast to the fine mode, we did not separate sea salt from the coarse mode. This was because AOD is typically less than 0.1 for pure maritime environments (Smirnov et al., 2002) while we tried to identify dominant aerosols when AOD was sufficiently high to obtain valid optical properties.

(5) Chemical properties of absorption aerosols in fine and coarse modes were distinguished, respectively, using the $K$-means clustering method (SPSS 12.0). As seen in Fig. 2, mineral dust (MD), MD mixed with carbon, and mixed coarse particles were grouped from the coarse mode, and $B C$ and $O C$ were grouped from the fine mode.

25 Proper numbers of clusters were determined by examining how correctly the discriminant function allocated the data into the same clusters (SPSS 12.0; Romesburg, 2004). The discriminant function was also used to classify dominant aerosols at worldwide AERONET sites into the aerosol types obtained from the Anmyon site.
ACPD

13, 26627-26656, 2013

Identification of column-integrated dominant aerosols

Y. Choi et al.

Title Page
Abstract

Conclusions

Tables

14

4

Back

\section{Introduction}

References

Figures

$>1$

$>$

Close
Full Screen / Esc

Printer-friendly Version

Interactive Discussion 


\section{Results and discussion}

\subsection{Optical properties of dominant aerosols}

The total number of the level 2 products at Anmyon for the study period was 1537. Two thirds of them (1033, number of the data) were classified as low AOD with AOD $<0.4$,

$510 \%(154)$ were removed because of the restriction of the imaginary refractive index, and $23 \%$ (350) were used for determining dominant aerosols. Among this $350,45 \%$ (157) had a characteristic of coarse mode with FMF $\leq 0.5$, while the remaining $55 \%$ (193) had a characteristic of fine mode with FMF $>0.5$.

Table 2 shows the optical properties of dominant aerosols distinguished in this work. $10 \mathrm{MD}$, for example, should be MD type dominant aerosols, but the former is used throughout the present work for simplicity's sake. As seen in Table 2, MD has much higher AOD than other aerosols. MD also has a very low FMF of 0.08 , and is considered as pure dust with a minimum contribution of fine mode aerosols (Kim et al., 2011). Similarly, high AODs were observed during the AD episode in El Arenosillo, Spain (Cachorro et al., 2008) and Beijing, China (Wu et al., 2009), which were 2.7 and 2.52, respectively. However, the fraction of MD is less than $1 \%$ of dominant aerosols, and most MD observed at Anmyon were mixed with carbon. Because carbon is predominantly occurs as fine particles, FMF of MD of mixed carbon increases to 0.22 even if it still remains low. SSA is basically not altered but AAE is lowered by mixing with carbon.

20 Bergstrom et al. (2007) showed the AAE of Asian dust with pollution to be 2.27 during the Asian Pacific Regional Aerosol Characterization Experiment (ACE-Asia), while that of Saharan dust was shown to be 2.34 during the Puerto Rico Dust Experiment (PRIDE). Cluster analyses of AERONET major sites revealed that AAE of desert dust aerosol was mostly 1.5-2.6 (Russell et al., 2010; Giles et al., 2012). AAE of MD in

Table 2 is slightly higher while that of MD mixed carbon is well between these values. In fact, Yang et al. (2009) indicated that the AAE of dust in Beijing measured by aethalometer was down to $1.82 \pm 0.90$ since dust aerosols were mixed with fine-mode

Identification of column-integrated dominant aerosols

Y. Choi et al.

Title Page

Abstract 
BC. AAE of dust measured by aethalometer at Gosan was even lower at 1.2-1.8, due to the inclusion of pollutants (Lee et al., 2012).

Mixed coarse particles are distinguished from MD and MD mixed with carbon as FMF increased. AOD, SSA and AAE decrease with increasing FMF. The fraction of 5 mixed coarse type aerosols is about $44 \%$, the largest among dominant aerosols. AOD is lower than other coarse-mode dominant aerosols, including MD, and is also lower than fine-mode dominant aerosols such as $\mathrm{BC}, \mathrm{OC}$ and secondary ions.

$B C$ and $O C$ do not show significant differences in AOD, SSA and FMF. However, AAE of $B C$ is obviously lower than OC. Kirchstetter et al. (2004) exhibited that AAE is 1 for $10 \mathrm{BC}$ emitted from high-temperature combustion processes, including diesel combustion, and 2 for $\mathrm{OC}$ from low-temperature combustion processes, including biomass burning. AAEs of carbonaceous aerosols from many studies are between these two values, which is also true in Table 2. AAEs from the International Consortium for Atmospheric Research on Transport and Transformation (ICARTT), and from the Tropical Aerosol 15 Radiative Forcing Observational Experiment (TARFOX) were 1.05 and 1.12, respectively, suggesting the dominant influence of diesel emissions in urban areas on the US Atlantic coast (Bergstrom et al., 2007). On the other hand, the AAE from Southern Africa Regional Science Initiative (SAFARI) 2000 to study biomass burning aerosols was 1.45 for a wavelength range of $300 \mathrm{~nm}$ to $1000 \mathrm{~nm}$ (Bergstrom et al., 2007).

20 AAEs from other cluster analyses are similar to Table 2 by considering that $\mathrm{BC}$ is dominant in urban and industrial areas, and that $O C$ is dominant in biomass burning (Russell et al., 2010; Giles et al., 2012). However, Giles et al. (2012) indicated that urban and industrial aerosols and biomass burning aerosols are more separable in SSA rather than in AAE. This is attributable to secondary ions such as ammonium sulfate and nitrate being included in urban and industrial aerosols not to carbonaceous aerosols. As seen in Fig. 2 we separated secondary ions when SSA was greater than 0.95 . AOD of secondary ions is higher than $B C$ and OC, and FMF and the fraction among dominant aerosols are also larger. In addition, SSA is the highest among dominant aerosols.

Identification of column-integrated dominant aerosols

Y. Choi et al.

Title Page

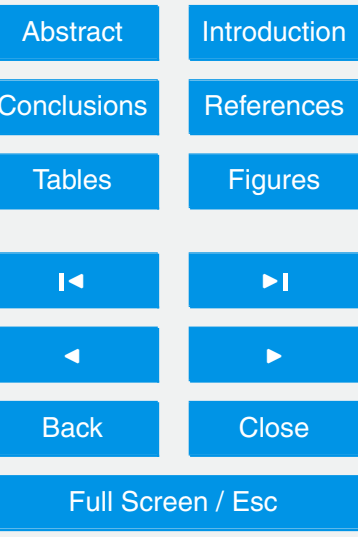

Printer-friendly Version

Interactive Discussion 26635 
SSA of secondary ions is high because of their colors which hinder absorption, but it increases with water vapor by hygroscopic growth (Eck et al., 2005). This is confirmed in Fig. 3, showing variations in the effective radius with respect to water vapor, and variations in SSA with respect to effective radius. The effective radius $\left(R_{\text {eff }}\right)$ is defined 5

$R_{\mathrm{eff}}=\frac{\int r^{3} \frac{\mathrm{d} N(r)}{\mathrm{d} \ln r} \mathrm{~d} \ln r}{\int r^{2} \frac{\mathrm{d} N(r)}{\mathrm{d} \ln r} \mathrm{~d} \ln r}$

where $r$ is the radius of aerosols and $N(r)$ is the number size distribution. The effective radius and water vapor are provided as inversion products of AERONET measurements. We used the effective radii of the fine mode in Fig. 3 because it is more relevant

to scattering.

In Fig. 3a secondary ions are distributed on the plane of higher effective radii and higher water vapor, since their effective radii generally increase in humid environment. The latter is due to the fact that secondary ions are frequent in summer, including rainy season, which will be discussed in the following section. On the other hand, MDs mixed with carbon are on the plane of lower effective radii and lower water vapor. This is not only because MDs mixed with carbon are frequent in dry season (to be discussed) and but also due to their hygroscopic growth being smaller (Kaaden et al., 2009; Lee et al., 2012). In Fig. 3b SSAs of secondary ions are higher since their effective radii (of the fine mode) are higher than those of other dominant aerosols, and are more efficient in scattering (Liou, 2002).

\subsection{Monthly variations in dominant aerosols}

Figure 4a shows the monthly variations in the occurrence rate of dominant aerosols. It also shows the variation of aerosols of low AOD, that is, AOD $<0.4$, and thus, shows the variation of the level 2 inversion product except that which was removed due to the restriction of imaginary refractive index (Fig. 2). The occurrence rate was calculated 26636

\section{ACPD}

13, 26627-26656, 2013

Identification of column-integrated dominant aerosols

Y. Choi et al.

Title Page
Abstract

Conclusions

Tables

14

4

Back
Introduction

References

Figures

$\rightarrow 1$

Close
Full Screen / Esc

Printer-friendly Version

Interactive Discussion 
by dividing the occurrence number of the aerosol type by the total number of daytime hours during which diffuse radiation could be measured. Here, we presume that diffuse radiation was measured at one hour intervals. The number of daytime hours was counted on a monthly basis by examining the earliest and latest times at which diffuse 5 radiation was measured.

In Fig. 4a the monthly sum of the occurrence rates varies from $9.6 \%$ in January to $1.4 \%$ in July. The average sum of occurrence rates was $4.7 \%$, which is the sum of $1.2 \%$ for dominant aerosols and $3.5 \%$ for low AOD aerosols. The sum is higher in the cold season between November and February, and lower in June and July. The latter o was due to high cloud amount during the rainy season (generally late June to midJuly) and a low solar zenith angle (SZA) at midday around the summer solstice (note that level 2 product is available when $S Z A \geq 50^{\circ}$ ). The sum except low AOD aerosols, that is, the sum of occurrence rates of dominant aerosols, is higher in March to May, which is mainly due to the large amount of mixed coarse particles. Since the fraction of mixed coarse particles is more than $40 \%$ of dominant aerosols, the variation in the occurrence rate of dominant aerosols is similar to that of mixed coarse particles.

MD, which was earlier presumed to be pure dust, is only observed in April. On the other hand, a significant fraction of MD mixed with carbon is observed throughout the period of March to May. In satellite observation, MD is generally mixed with carbon

(Higurashi and Nakajima, 2002; J. Kim et al., 2007). Many measurement works on the ground in Korea and in Northeast Asia also reported that SSA of MD was lowered due to mixing with carbon and other pollutants (Bates et al., 2004; S.-W. Kim et al., 2005, 2007; Yang et al., 2009; Jung et al., 2010; Lee et al., 2012). Since the fraction of mixed coarse particles is also high in March to May, coarse aerosols are dominant in this period. This phenomenon is attributable to higher wind speeds and dry conditions, which are favorable for the generation of fugitive dust, along with the inflow of Asian dust (KMA, 2001).

It is apparent that $\mathrm{BC}$ is high in the cold season due to the increase in fuel combustion for heating. However, in Fig. $4 \mathrm{~b}$ the fraction of $B C$ is significant except for a few
ACPD

13, 26627-26656, 2013

Identification of column-integrated dominant aerosols

Y. Choi et al.

Title Page
Abstract

Conclusions

Tables

14

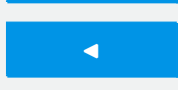

Back
References

Figures

$\rightarrow 1$

Close

\section{Introduction}

Full Screen / Esc

Printer-friendly Version

Interactive Discussion 
months. This is caused by vehicular emissions whose effects are consistent year-round but are diminished due to dispersion by strong winds in April, and due to scavenging by precipitation in July and August. OC is similar because biomass burning or other combustion producing OC is ubiquitous in the study area (Duan et al., 2004; S.-W. Kim 5 et al., 2007; Lim et al., 2012). In contrast, the occurrence rate of secondary ions is high in the hot summer months of July and August in which photochemical reactions are active; their fraction is significant from June and October. Considerable fractions of secondary ions are also observed in January and February, probably because semivolatile secondary ions, e.g., ammonium nitrate are favorable for low temperature and 10 high relative humidity (Ansari and Pandis, 1998; Lee et al., 1999; NARSTO, 2004).

\subsection{Dominant aerosols at selected AERONET sites}

As mentioned earlier we classified dominant aerosols at worldwide AERONET sites into the aerosols types identified for the Anmyon site (Table 2). The AERONET sites selected are known to have characteristics of urban/industrial (Beijing, Mexico City, 15 Goddard Space Flight Center [GSFC] in a suburb of Washington, D.C.), biomass burning (Mongu, Alta Floresta), and dust (Cape Verde) (Dubovik et al., 2002; Arola et al., 2011; Giles et al., 2012; Eck et al., 2013). We primarily analyzed dominant aerosols at Beijing, Mexico City, and GSFC by comparing with those at Mongu and Alta Floresta as typical types of fine mode aerosols from biomass burning and Cape Verde as typical 20 types of coarse mode aerosols from desert dust.

In Fig. 5, we examine the occurrence of aerosol types at the selected sites. Beijing is a megacity which has heavy aerosol loading generated from various types of fossil fuel combustion, as well as from deserts in the surrounding areas (Yu et al., 2009; Wang et al., 2011). Heavy aerosol loading at Beijing is confirmed by a high occurrence rate of dominant aerosols, which is $6.3 \%$, the highest among seven sites, more than five times that at Anmyon. The occurrence rates at Mongu and Cape Verde are the next but one third of that at Bejing. Although the highest occurrence rate at Beijing is primarily due to the coarse mode, the occurrence rate of the fine mode is also the highest (Eck

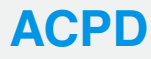

13, 26627-26656, 2013

Identification of column-integrated dominant aerosols

Y. Choi et al.

Title Page

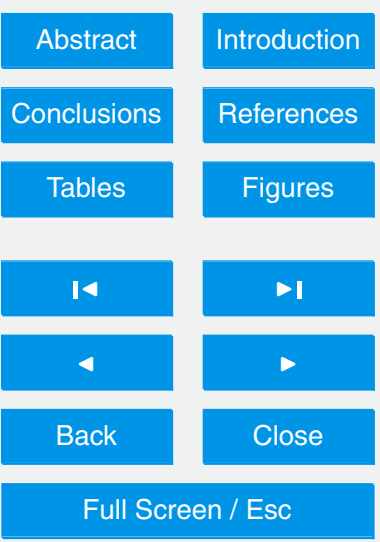

Printer-friendly Version

Interactive Discussion 
et al., 2005, 2010). Major constituents of dominant aerosols at Beijing are BC, OC, and MD mixed with carbon, except mixed coarse particles whose properties are not well characterized. At Beijing, the sum of the occurrence rates of MD and MD mixed with carbon is $0.87 \%$, next to $1.43 \%$ at Cape Verde, and the sum of the occurrence rates 5 of $\mathrm{BC}$ and $\mathrm{OC}$ is $2.03 \%$, next to $2.10 \%$ at Mongu.

Figure 6 shows the mean optical properties of major categories of dominant aerosols by AERONET site. AOD at Beijing is the highest for all categories, denoting high aerosol loading regardless of aerosol types. It is notable that differences in AOD between Beijing and other sites are higher for carbonaceous aerosols and secondary 0 ions, that is, for the fine mode than those for the coarse mode. Furthermore, the mean AOD of secondary ions is higher than that of MD including MD+carbon (MDs hereafter). This means that AOD is generally higher when secondary ions are dominant than when mineral dust is dominant, although their occurrence rate is lower than that of MDs. Eck et al. (2005) explained that high AOD is due to hygroscopic growth in the column associated with high relative humidity in summer. They also mentioned that this high AOD is manifested by infrequent high-pressure systems in summer, leading to clear sky adequate for sun photometer measurements. On the other hand, generally lower SSAs of dominant aerosols at Beijing compared to other sites are attributable to the prevalence of carbonaceous materials (Eck et al., 2010; Lee et al., 2010). SSAs of $\mathrm{MDs}$ and $\mathrm{BC}+\mathrm{OC}$ at Beijing are only higher than those at Mongu where the fraction of $\mathrm{BC}+\mathrm{OC}$ among dominant aerosols approaches $100 \%$ (Fig. 5b).

Mexico City is another megacity, along with Beijing, which is infamous for the severity of its air pollution (WHO/UNEP, 1992). In Fig. 5, however, the occurrence rate of dominant aerosols at Mexico City is much less than that in Beijing (Querol et al., 2008), rather similar to Anmyon. A distinct feature of dominant aerosols at Mexico City in comparison with Beijing and Anmyon is the little occurrence of MDs and large fraction of fine particles. This is different from other studies (Querol et al., 2008; Karydis et al., 2011), indicating an importance of mineral dust on the level of particulate matter in the Mexico City metropolitan area. This could result from the fact that mineral dust at
ACPD

13, 26627-26656, 2013

Identification of column-integrated dominant aerosols

Y. Choi et al.

Title Page

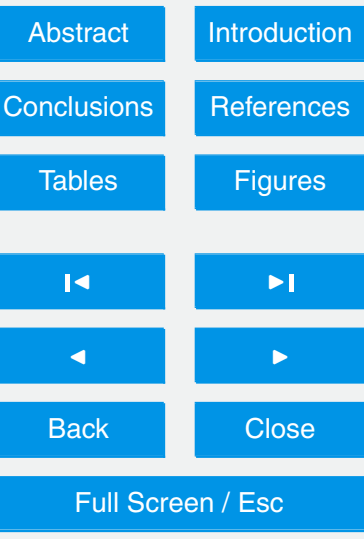

Printer-friendly Version

Interactive Discussion 
Mexico City is fugitive and is locally generated in an isolated high-altitude basin, while those of Beijing and Anmyon are originated from distant desert areas which are devoid of major pollution sources. As a result, it is probable that dust over Mexico City is classified as a mixed coarse particle with pollutants rather than typical mineral dust. MDs at

5 Mexico City, despite little fraction, show a large AOD, only next to Beijing, and a large AAE similar to that at Cape Verde, and a large FMF similar to that at Alta Floresta (Fig. 6). The AOD of MDs is also large at Mongu and Alta Floresta, where the fraction of MDs is similarly little with Mexico City, while it is smaller at Cape Verde despite dominant fraction of MDs. The distinct effect of MDs at Cape Verde is only confirmed with 10 the lowest FMF (Kim et al., 2011); AAE is the highest for MDs at Cape Verde (Russell et al., 2010). Relatively larger FMF of MDs at Mexico City, as well as those at Mongu and Alta Floresta, represents that high aerosol loadings with high AOD at those sites are generally influenced by the fine mode even in the case of MDs.

GSFC is distinguished from other sites by high occurrence rate of secondary ions 15 (Fig. 5) (Dubovik et al., 2002; Eck et al., 2005). Among the dominant aerosols, $84 \%$ are secondary ions, $14 \%$ is $\mathrm{BC}$, and the remainder is classified as mixed coarse particles. As a result, the occurrence rate of the coarse mode as well as its fraction is the least among the seven study sites (Dubovik et al., 2002). Mean optical properties of dominant aerosol types are characterized by lower AOD and AAE, but higher SSA and FMF (Fig. 6). Lower AOD is probably due to the effects of secondary ions whose $A O D$ is generally lower than those of MDs and $B C+O C$ (Table 2), although dominant aerosol types were deliberately classified according to their optical properties. Other characteristics such as lower AAE, and higher SSA and FMF are similarly interpreted. It is interesting that SSA is the highest for secondary ions at Mongu, where the fraction of secondary ions is minimal. However, as mentioned earlier, SSA is the lowest for MDs at Mongu where their fraction is also minimal. It is presumed that typical characteristics of aerosol types are emphasized with minimal occurrence rates, and become weakened with increases in the occurrence rate by mingling with less typical aerosol types.
ACPD

13, 26627-26656, 2013

Identification of column-integrated dominant aerosols

Y. Choi et al.

Title Page

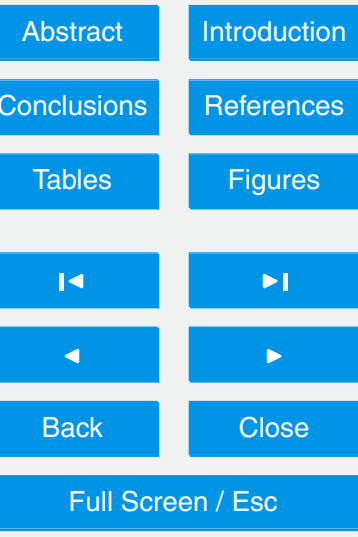

Printer-friendly Version

Interactive Discussion 


\section{Summary and conclusions}

Dominant aerosol types at the Anmyon site were identified using the archive of AERONET data set between 1999 and 2007. While the site is regarded as a rural or background site in Korea, it was classified as a polluted continental site due to the 5 effects of the transport of pollutants from the Asian Continent (Eck et al., 2005; Omar et al., 2005). MD, MD mixed with carbon, and mixed coarse particles for coarse mode aerosols and $\mathrm{BC}, \mathrm{OC}$, and secondary ions for fine mode aerosols were distinguished as dominant aerosols.

MD has much higher AOD and AAE and very low FMF. However, the fraction of MD 10 among dominant aerosols is less than $1 \%$ and most MD at Anmyon is mixed with carbon. The fraction of coarse mode aerosols including MD, MD mixed with carbon, and mixed coarse particles, is higher in March to May in which meteorological conditions, such as higher wind speeds and dry conditions, are favorable for the generation of fugitive dust, along with inflow of Asian dust. While the AAE of BC is close to 1, the lowest 15 among dominant aerosols, optical properties of $B C$ and $O C$ are similar except for $A A E$. The fractions of $\mathrm{BC}$ and $\mathrm{OC}$ are variable but consistent due to various combustion sources, such vehicular emissions and biomass burning. These fractions are low in April due to dispersion by strong winds, and in July and August due to scavenging by precipitation. Secondary ions are most frequent in July and August when photochemical reactions are active. They have the highest SSA and FMF, and their AOD is higher than $\mathrm{BC}$ and $\mathrm{OC}$. The effective radii of secondary ions are generally larger when the water vapor content is high due to hygroscopic growth, which results in higher SSA.

Occurrences and optical properties of dominant aerosols at worldwide AERONET sites with distinct aerosol characteristics were examined by allocating them into the same aerosol types identified at Anmyon. Among selected urban/industrial sites, Beijing is characterized by major effects of coarse mode aerosols such as MD and MD mixed with carbon, but the effects of fine mode aerosols, including carbonaceous aerosols and secondary ions, are also substantial. As a result, the occurrence rate of
ACPD

13, 26627-26656, 2013

Identification of column-integrated dominant aerosols

Y. Choi et al.

Title Page
Abstract

Conclusions

Tables

14

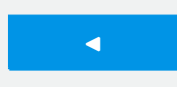

Back

\section{Introduction}

References

Figures

$\rightarrow 1$

$>$

Close
Full Screen / Esc

Printer-friendly Version

Interactive Discussion 
dominant aerosols, that is AOD $>0.4$, is the greatest among the study sites. Although it is possible to discriminate major characteristics of dominant aerosols at the study sites, their optical properties are generally influenced by the aerosol types with large fractions, for example, mineral dust at Beijing, carbonaceous aerosols at Mexico City, and 5 secondary ions at GSFC. One probable reason is because dominant aerosols, which are physically and chemically characterized, are distinguished from the dataset of optical properties on the basis of previous works, not by physical and chemical measurements. However, it could also be because dominant aerosols are column-integrated and because mean optical properties from a number of occurrences are compared. 10 Close investigation of the meaning and effectiveness of column-integrated dominant aerosols from the dataset of optical properties is warranted.

Acknowledgements. This work was funded by the Korea Meteorological Administration Research and Development Program under the Grant CATER 2012-7130.

\section{References}

15 Ångström, A.: Techniques of determinig the turbidity of the atmosphere, Tellus, 13, 214-223, doi:10.1111/j.2153-3490.1961.tb00078.x, 1961.

Ansari, A. S. and Pandis, S. N.: Response of inorganic PM to precursor concentrations, Environ. Sci. Technol., 32, 2706-2714, doi:10.1021/es971130j, 1998.

Arola, A., Schuster, G., Myhre, G., Kazadzis, S., Dey, S., and Tripathi, S. N.: Inferring absorbing organic carbon content from AERONET data, Atmos. Chem. Phys., 11, 215-225, doi:10.5194/acp-11-215-2011, 2011.

Bates, T. S., Quinn, P. K., Coffman, D. J., Covert, D. S., Miller, T. L., Johnson, J. E., Carmichael, G. R., Uno, I., Guazzotti, S. A., Sodeman, D. A., Prather, K. A., Rivera, M., Russell, L. M., and Merrill, J. T.: Marine boundary layer dust and pollutant transport associated with the passage of a frontal system over eastern Asia, J. Geophys. Res., 109, D19S19, doi:10.1029/2003JD004094, 2004.

Bergstrom, R. W., Pilewskie, P., Pommier, J., Rabbette, M., Russell, P. B., Schmid, B., Redemann, J., Higurashi, A., Nakajima, T., and Quinn, P. K.: Spectral absorption of solar radiation

\section{ACPD}

13, 26627-26656, 2013

Identification of column-integrated dominant aerosols

Y. Choi et al.

Title Page
Full Screen / Esc

Printer-friendly Version

Interactive Discussion 
by aerosols during ACE-Asia, J. Geophys. Res., 109, D19S15, doi:10.1029/2003jd004467, 2004.

Bergstrom, R. W., Pilewskie, P., Russell, P. B., Redemann, J., Bond, T. C., Quinn, P. K., and Sierau, B.: Spectral absorption properties of atmospheric aerosols, Atmos. Chem. Phys., 7, 5 5937-5943, doi:10.5194/acp-7-5937-2007, 2007.

Cachorro, V. E., Toledano, C., Prats, N., Sorribas, M., Mogo, S., Berjón, A., Torres, B., Rodrigo, R., de la Rosa, J., and De Frutos, A. M.: The strongest desert dust intrusion mixed with smoke over the Iberian Peninsula registered with Sun photometry, J. Geophys. Res., 113, D14S04, doi:10.1029/2007JD009582, 2008.

10 Chin, M., Diehl, T., Dubovik, O., Eck, T. F., Holben, B. N., Sinyuk, A., and Streets, D. G.: Light absorption by pollution, dust, and biomass burning aerosols: a global model study and evaluation with AERONET measurements, Ann. Geophys., 27, 3439-3464, 2009, http://www.ann-geophys.net/27/3439/2009/.

Duan, F., Liu, X., Yu, T., and Cachier, H.: Identification and estimate of biomass burning con15 tribution to the urban aerosol organic carbon concentrations in Beijing, Atmos. Environ., 38, 1275-1282, doi:10.1016/j.atmosenv.2003.11.037, 2004.

Dubovik, O., Smirnov, A., Holben, B. N., King, M. D., Kaufman, Y. J., Eck, T. F., and Slutsker, I.: Accuracy assessments of aerosol optical properties retrieved from Aerosol Robotic Network (AERONET) Sun and sky radiance measurements, J. Geophys. Res., 105, 9791-9806, doi:10.1029/2000jd900040, 2000.

Dubovik, O., Holben, B., Eck, T. F., Smirnov, A., Kaufman, Y. J., King, M. D., Tanré, D., and Slutsker, I.: Variability of absorption and optical properties of key aerosol types observed in worldwide locations, J. Atmos. Sci., 59, 590-608, doi:10.1175/15200469(2002)059<0590:VOAAOP>2.0.CO;2, 2002.

Dubovik, O., Sinyuk, A., Lapyonok, T., Holben, B. N., Mishchenko, M., Yang, P., Eck, T. F., Volten, H., Muñoz, O., Veihelmann, B., van der Zande, W. J., Leon, J.-F., Sorokin, M., and Slutsker, I.: Application of spheroid models to account for aerosol particle nonsphericity in remote sensing of desert dust, J. Geophys. Res., 111, D11208, doi:10.1029/2005jd006619, 2006.

so Eck, T. F., Holben, B. N., Reid, J. S., Dubovik, O., Smirnov, A., O’Neill, N. T., Slutsker, I., and Kinne, S.: Wavelength dependence of the optical depth of biomass burning, urban, and desert dust aerosols, J. Geophys. Res., 104, 31333-31349, doi:10.1029/1999jd900923, 1999.

\section{ACPD}

13, 26627-26656, 2013

Identification of column-integrated dominant aerosols

Y. Choi et al.

Title Page

Abstract

\section{Full Screen / Esc}

Printer-friendly Version

Interactive Discussion 
Eck, T. F., Holben, B. N., Dubovik, O., Smirnov, A., Goloub, P., Chen, H. B., Chatenet, B., Gomes, L., Zhang, X. Y., Tsay, S. C., Ji, Q., Giles, D., and Slutsker, I.: Columnar aerosol optical properties at AERONET sites in central eastern Asia and aerosol transport to the tropical mid-Pacific, J. Geophys. Res., 110, D06202, doi:10.1029/2004jd005274, 2005.

5 Eck, T. F., Holben, B. N., Sinyuk, A., Pinker, R. T., Goloub, P., Chen, H., Chatenet, B., Li, Z., Singh, R. P., Tripathi, S. N., Reid, J. S., Giles, D. M., Dubovik, O., O’Neill, N. T., Smirnov, A., Wang, P., and Xia, X.: Climatological aspects of the optical properties of fine/coarse mode aerosol mixtures, J. Geophys. Res., 115, D19205, doi:10.1029/2010jd014002, 2010.

Eck, T. F., Holben, B. N., Reid, J. S., Mukelabai, M. M., Piketh, S. J., Torres, O., Jethva, H. T., Hyer, E. J., Ward, D. E., Dubovik, O., Sinyuk, A., Schafer, J. S., Giles, D. M., Sorokin, M., Smirnov, A., and Slutsker, I.: A seasonal trend of single scattering albedo in southern African biomass-burning particles: implications for satellite products and estimates of emissions for the world's largest biomass-burning source, J. Geophys. Res., 118, 6414-6432, doi:10.1002/jgrd.50500, 2013.

Giles, D. M., Holben, B. N., Eck, T. F., Sinyuk, A., Smirnov, A., Slutsker, I., Dickerson, R. R., Thompson, A. M., and Schafer, J. S.: An analysis of AERONET aerosol absorption properties and classifications representative of aerosol source regions, J. Geophys. Res., 117, D17203, doi:10.1029/2012jd018127, 2012.

Higurashi, A. and Nakajima, T.: Detection of aerosol types over the East China Sea near Japan from four-channel satellite data, Geophys. Res. Lett., 29, 1836, doi:10.1029/2002GL015357, 2002.

Holben, B. N., Tanré, D., Smirnov, A., Eck, T. F., Slutsker, I., Abuhassan, N., Newcomb, W. W., Schafer, J. S., Chatenet, B., Lavenu, F., Kaufman, Y. J., Castle, J. V., Setzer, A., Markham, B., Clark, D., Frouin, R., Halthore, R., Karneli, A., O’Neill, N. T., Pietras, C., Pinker, R. T., Voss, K., and Zibordi, G.: An emerging ground-based aerosol climatology: aerosol optical depth from AERONET, J. Geophys. Res., 106, 12067-12097, doi:10.1029/2001jd900014, 2001.

Holben, B., Eck, T. F., Slutsker, I., Smirnov, A., Sinyuk, A., Schafer, J., Giles, D., and Dubovik, O.: AERONET's Version 2.0 quality assurance criteria. AERONET Technical and Quality Assurance Documents, available at: http://aeronet.gsfc.nasa.gov/new_web/PDF/AERONETcriteria_final1.pdf, last access: October 2013.

IPCC, 2007: Climate Change 2007: The Physical Science Basis, Contribution of Working Group I to the Fourth Assessment Report of the Intergovernmental Panel on Climate Change, edited
ACPD

13, 26627-26656, 2013

Identification of column-integrated dominant aerosols

Y. Choi et al.

Title Page

Abstract

Introduction

Conclusions

References

Tables

Figures

14

$\rightarrow 1$

4

Back

Close 
by: Solomon, S., Qin, D., Manning, M., Chen, Z., Marquis, M., Averyt, K. B., Tignor, M., and Miller, H. L., Cambridge University Press, Cambridge, UK and New York, NY, USA, 996 pp., 2007.

Jung, J., Kim, Y. J., Lee, K. Y., Cayetano, M. G., Batmunkh, T., Koo, J.-H., and Kim, J.: Spectral 5 optical properties of long-range transport Asian dust and pollution aerosols over Northeast Asia in 2007 and 2008, Atmos. Chem. Phys., 10, 5391-5408, doi:10.5194/acp-10-53912010, 2010.

Kaaden, N., Massling, A., Schladitz, A., Müller, T., Kandler, K., Schütz, L., Weinzierl, B., Petzold, A., Tesche, M., Leinert, S., Deutscher, C., Ebert, M., Weinbruch, S., and Wiedensohler, A.: State of mixing, shape factor, number size distribution, and hygroscopic growth of the Saharan anthropogenic and mineral dust aerosol at Tinfou, Morocco, Tellus B, 61, 51-63, doi:10.1111/j.1600-0889.2008.00388.x, 2009.

Karydis, V. A., Tsimpidi, A. P., Lei, W., Molina, L. T., and Pandis, S. N.: Formation of semivolatile inorganic aerosols in the Mexico City Metropolitan Area during the MILAGRO campaign,

Atmos. Chem. Phys., 11, 13305-13323, doi:10.5194/acp-11-13305-2011, 2011.

Kim, D., Chin, M., Yu, H., Eck, T. F., Sinyuk, A., Smirnov, A., and Holben, B. N.: Dust optical properties over North Africa and Arabian Peninsula derived from the AERONET dataset, Atmos. Chem. Phys., 11, 10733-10741, doi:10.5194/acp-11-10733-2011, 2011.

Kim, J., Lee, J., Lee, H. C., Higurashi, A., Takemura, T., and Song, C. H.: Consistency of the aerosol type classification from satellite remote sensing during the Atmospheric Brown Cloud-East Asia Regional Experiment campaign, J. Geophys. Res., 112, D22S33, doi:10.1029/2006jd008201, 2007.

Kim, S.-W., Yoon, S.-C., Jefferson, A., Ogren, J. A., Dutton, E. G., Won, J.-G., Ghim, Y. S., Lee, B.-I., and Han, J.-S.: Aerosol optical, chemical and physical properties at Gosan, Korea during Asian dust and pollution episodes in 2001, Atmos. Environ., 39, 39-50, doi:10.1016/j.atmosenv.2004.09.056, 2005.

Kim, S.-W., Yoon, S.-C., Kim, J., and Kim, S.-Y.: Seasonal and monthly variations of columnar aerosol optical properties over east Asia determined from multi-year MODIS, LIDAR, and AERONET Sun/sky radiometer measurements, Atmos. Environ., 41, 1634-1651, doi:10.1016/j.atmosenv.2006.10.044, 2007.

Kirchstetter, T. W., Novakov, T., and Hobbs, P. V.: Evidence that the spectral dependence of light absorption by aerosols is affected by organic carbon, J. Geophys. Res., 109, D21208, doi:10.1029/2004jd004999, 2004.

\section{ACPD}

13, 26627-26656, 2013

Identification of column-integrated dominant aerosols

Y. Choi et al.

Title Page
Abstract

Conclusions

Tables

14

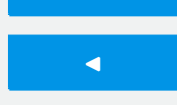

Back

\section{Introduction}

References

Figures

$>1$

$>$

Close
Full Screen / Esc

Printer-friendly Version

Interactive Discussion 
KMA: Climatological Normals of Korea, Korea Meteorological Administration, Seoul, Korea, 2001.

Lee, H. S., Kang, C.-M., Kang, B.-W., and Kim, H.-K.: Seasonal variations of acidic air pollutants in Seoul, South Korea, Atmos. Environ., 33, 3143-3152, doi:10.1016/S1352-2310(98)00382$5 \quad 3,1999$.

Lee, J., Kim, J., Song, C. H., Kim, S. B., Chun, Y., Sohn, B. J., and Holben, B. N.: Characteristics of aerosol types from AERONET sunphotometer measurements, Atmos. Environ., 44, 31103117, doi:10.1016/j.atmosenv.2010.05.035, 2010.

Lee, S., Yoon, S.-C., Kim, S.-W., Kim, Y. P., Ghim, Y. S., Kim, J.-H., Kang, C.-H., Kim, Y. J., Chang, L.-S., and Lee, S.-J.: Spectral dependency of light scattering/absorption and hygroscopicity of pollution and dust aerosols in Northeast Asia, Atmos. Environ., 50, 246-254, doi:10.1016/j.atmosenv.2011.12.026, 2012.

Levy, R. C., Remer, L. A., and Dubovik, O.: Global aerosol optical properties and application to Moderate Resolution Imaging Spectroradiometer aerosol retrieval over land, J. Geophys.

15 Res., 112, D13210, doi:10.1029/2006jd007815, 2007.

Lim, S., Lee, M., Lee, G., Kim, S., Yoon, S., and Kang, K.: Ionic and carbonaceous compositions of $\mathrm{PM}_{10}, \mathrm{PM}_{2.5}$ and $\mathrm{PM}_{1.0}$ at Gosan $\mathrm{ABC}$ Superstation and their ratios as source signature, Atmos. Chem. Phys., 12, 2007-2024, doi:10.5194/acp-12-2007-2012, 2012.

Liou, K. N.: An Introduction to Atmospheric Radiation, 2nd edn., Academic Press, 2002.

20 Logan, T., Xi, B., Dong, X., Li, Z., and Cribb, M.: Classification and investigation of Asian aerosol absorptive properties, Atmos. Chem. Phys., 13, 2253-2265, doi:10.5194/acp-13-2253-2013, 2013.

Mielonen, T., Arola, A., Komppula, M., Kukkonen, J., Koskinen, J., de Leeuw, G., and Lehtinen, K. E. J.: Comparison of CALIOP level 2 aerosol subtypes to aerosol types derived from AERONET inversion data, Geophys. Res. Lett., 36, L18804, doi:10.1029/2009gl039609, 2009.

NARSTO: Particulate Matter Assessment for Policy Makers: a NARSTO Assessment, edited by: McMurry, P., Shepherd, M., and Vickery, J., Cambridge University Press, Cambridge, England, 2004.

so Omar, A. H., Won, J.-G., Winker, D. M., Yoon, S.-C., Dubovik, O., and McCormick, M. P.: Development of global aerosol models using cluster analysis of Aerosol Robotic Network (AERONET) measurements, J. Geophys. Res., 110, D10S14, doi:10.1029/2004jd004874, 2005.

Identification of column-integrated dominant aerosols

Y. Choi et al.

Title Page

\section{Full Screen / Esc}

Printer-friendly Version

Interactive Discussion 
Prats, N., Cachorro, V. E., Berjón, A., Toledano, C., and De Frutos, A. M.: Column-integrated aerosol microphysical properties from AERONET Sun photometer over southwestern Spain, Atmos. Chem. Phys., 11, 12535-12547, doi:10.5194/acp-11-12535-2011, 2011.

Querol, X., Pey, J., Minguillón, M. C., Pérez, N., Alastuey, A., Viana, M., Moreno, T., Bernabé, R. M., Blanco, S., Cárdenas, B., Vega, E., Sosa, G., Escalona, S., Ruiz, H., and Artíñano, B.: PM speciation and sources in Mexico during the MILAGRO-2006 Campaign, Atmos. Chem. Phys., 8, 111-128, doi:10.5194/acp-8-111-2008, 2008.

Quinn, P. K. and Bates, T. S.: Regional aerosol properties: comparisons of boundary layer measurements from ACE 1, ACE 2, Aerosols99, INDOEX, ACE Asia, TARFOX, and NEAQS, J. Geophys. Res., 110, D14202, doi:10.1029/2004jd004755, 2005.

Romesburg, H. C.: Cluster Analysis For Researchers, Lulu Press, North Carolina, 258 pp., 2004.

Russell, P. B., Redemann, J., Schmid, B., Bergstrom, R. W., Livingston, J. M., McIntosh, D. M., Ramirez, S. A., Hartley, S., Hobbs, P. V., Quinn, P. K., Carrico, C. M., Rood, M. J., Öström, E., Noone, K. J., von Hoyningen-Huene, W., and Remer, L.: Comparison of aerosol single scattering albedos derived by diverse techniques in two North Atlantic experiments, J. Atmos. Sci., 59, 609-619, doi:10.1175/1520-0469(2002)059<0609:COASSA>2.0.CO;2, 2002.

Russell, P. B., Bergstrom, R. W., Shinozuka, Y., Clarke, A. D., DeCarlo, P. F., Jimenez, J. L., Livingston, J. M., Redemann, J., Dubovik, O., and Strawa, A.: Absorption Angstrom Exponent in AERONET and related data as an indicator of aerosol composition, Atmos. Chem. Phys., 10, 1155-1169, doi:10.5194/acp-10-1155-2010, 2010.

Schafer, J. S., Eck, T. F., Holben, B. N., Artaxo, P., and Duarte, A. F.: Characterization of the optical properties of atmospheric aerosols in Amazônia from long-term AERONET monitoring (1993-1995 and 1999-2006), J. Geophys. Res., 113, D04204, doi:10.1029/2007JD009319, 2008.

Schuster, G. L., Dubovik, O., and Holben, B. N.: Angstrom exponent and bimodal aerosol size distribution, J. Geophys. Res., 111, D07207, doi:10.1029/2005JD006328, 2006.

Smirnov, A., Holben, B. N., Eck, T. F., Dubovik, O., and Slutsker, I.: Cloud-screening and quality control algorithms for the AERONET database, Remote Sens. Environ., 73, 337-349, doi:10.1016/s0034-4257(00)00109-7, 2000.

Smirnov, A., Holben, B. N., Kaufman, Y. J., Dubovik, O., Eck, T. F., Slutsker, I., Pietras, C., and Halthore, R. N.: Optical properties of atmospheric aerosol in maritime environments, J. Atmos. Sci., 59, 501-523, doi:10.1175/1520-0469(2002)059<0501:OPOAAl>2.0.CO;2, 2002.
ACPD

13, 26627-26656, 2013

Identification of column-integrated dominant aerosols

Y. Choi et al.

Title Page 
Takamura, T., Nakajima, T., and SKYNET Community Group: Overview of SKYNET and its activities, Opt. Pur. y Apl., 37, 3303-3308, 2004.

Wang, S., Fang, L., Gu, X., Yu, T., and Gao, J.: Comparison of aerosol optical properties from Beijing and Kanpur, Atmos. Environ., 45, 7406-7414, doi:10.1016/j.atmosenv.2011.06.055, 52011.

WHO/UNEP (World Health Organization/United Nations Environment Programme): Urban Air Pollution in Megacities of the World, Blackwell, Oxford, 1992.

WMO (World Meteorological Organization): WMO/GAW Experts Workshop on a Global Surface-based Network for Long Term Observations of Column Aerosol Optical Properties. Davos, Switzerland, 8-10 March 2004, World Meteorological Organization, Geneva, Switzerland, WMO TD No. 1287, available at: ftp://ftp.wmo.int/Documents/PublicWeb/arep/gaw/gaw162.pdf, 2005.

Wu, Z. J., Cheng, Y. F., Hu, M., Wehner, B., Sugimoto, N., and Wiedensohler, A.: Dust events in Beijing, China (2004-2006): comparison of ground-based measurements with columnar integrated observations, Atmos. Chem. Phys., 9, 6915-6932, doi:10.5194/acp-9-6915-2009, 2009.

Yang, M., Howell, S. G., Zhuang, J., and Huebert, B. J.: Attribution of aerosol light absorption to black carbon, brown carbon, and dust in China - interpretations of atmospheric measurements during EAST-AIRE, Atmos. Chem. Phys., 9, 2035-2050, doi:10.5194/acp-9-2035$20 \quad 2009,2009$.

Yu, X., Zhu, B., and Zhang, M.: Seasonal variability of aerosol optical properties over Beijing, Atmos. Environ., 43, 4095-4101, doi:10.1016/j.atmosenv.2009.03.061, 2009.

\section{ACPD}

13, 26627-26656, 2013

Identification of column-integrated dominant aerosols

Y. Choi et al.

\section{Title Page}

\section{Full Screen / Esc}

Printer-friendly Version

Interactive Discussion 
Table 1. Selected works for classification of dominant aerosol types using optical properties.

\begin{tabular}{|c|c|c|c|c|}
\hline Date Source & Reference & Parameters $^{\mathrm{a}}$ & Study area (period) & Aerosol type \\
\hline \multirow[t]{6}{*}{ AERONET } & This study & $\mathrm{AOD}_{440}, \mathrm{SSA}_{440}, \mathrm{AAE}_{440-1020}, \mathrm{FMF}$ & Anmyon, Korea (1999-2007) & $\begin{array}{l}\text { Mineral dust, mineral dust + carbon, mixed coarse, BC, } \\
\text { OC, secondary ions }\end{array}$ \\
\hline & Omar et al. (2005) & 26 variables $^{\mathrm{b}}$ of $\mathrm{AERONET}$ & Worldwide (> 250 sites; up to 2002) & $\begin{array}{l}\text { Desert dust, biomass burning, background/rural, pol- } \\
\text { luted continental, polluted marine, dirty pollution }\end{array}$ \\
\hline & Russell et al. (2010) & $\mathrm{AAE}_{870 / 440}, \mathrm{AE}_{870 / 440}$ & Worldwide (11 sites; up to 2000 ) & Urban-industrial, biomass burning, desert dust \\
\hline & Lee et al. (2010) & $\mathrm{FMF}_{550}, \mathrm{SSA}_{440}$ & Worldwide (not specified) & $\begin{array}{l}\text { Dust, non-absorbing, slightly-absorbing, } \\
\text { moderately absorbing, highly-absorbing }\end{array}$ \\
\hline & Giles et al. (2012) & $\mathrm{SSA}_{440}, \mathrm{AAE}_{440-870}, \mathrm{AE}_{440-870}, \mathrm{FMF}_{550}$ & Worldwide (1999-2010) & Dust, mixed, urban/industrial, biomass burning \\
\hline & Logan et al. (2013) & $\mathrm{AE}_{440-870}, 1-\mathrm{SSA}_{440}$ & East Asia (4 sites, 2001-2010) & $\begin{array}{l}\text { Weakly absorbing fine mode, strongly absorbing fine } \\
\text { mode, strongly absorbing coarse mode, weakly ab- } \\
\text { sorbing coarse mode }\end{array}$ \\
\hline $\begin{array}{l}\text { MODIS and } \\
\text { OMI }\end{array}$ & Kim et al. (2007) & FMF (MODIS), Al (OMI) & East Asia (ABC-EAREX; 2005) & Dust, carbonaceous, sea salt, sulfate \\
\hline $\begin{array}{l}\text { AERONET and } \\
\text { CALIOP }\end{array}$ & Mielonen et al. (2009) & $\begin{array}{l}\mathrm{SSA}_{440}, \mathrm{AE}_{440-870} \text { (AERONET), depo- } \\
\text { larization ratio, integrated attenuated } \\
\text { back scatter coefficient, surface type, } \\
\text { layer heights (CALIOP) }\end{array}$ & $\begin{array}{l}\text { Worldwide (38 AERONET sites; } \\
\text { since Jun 2006) }\end{array}$ & $\begin{array}{l}\text { Dust, polluted dust, biomass burning, marine, clean, } \\
\text { polluted continental }\end{array}$ \\
\hline $\begin{array}{l}\text { In situ chemical } \\
\text { and physical } \\
\text { measurements }\end{array}$ & Yang et al. (2009) & $\mathrm{AAE}_{370-950}, \mathrm{AE}_{450-700}$ & Xianghe, China (2005.3.2-3.26) & $\begin{array}{l}\text { Biomass burning, dust, fresh plume, coal pollution, } \\
\text { background air }\end{array}$ \\
\hline
\end{tabular}

${ }^{\mathrm{a}} \phi_{\lambda}=\phi$ at $\lambda \mathrm{nm} ; \mathrm{AE}_{\lambda 1-\lambda 2}$ (or $A A E_{\lambda 1-\lambda 2}$ ) = slope from the plot of In $A O D$ (or In $A A O D$ ) vs. In $\lambda ; A E_{\lambda 2 / \lambda 1}$ (or $A A E_{\lambda 2 / \lambda 1}$ ) = slope from the two values of In $A O D$ (or In $A A O D)$ at $\ln \lambda 1$ and $\ln \lambda 2$.

${ }^{b}$ Complex refractive index (8), mean radius (2), single scattering albedo (4), standard deviation (2), asymmetry factor (4), mode total volume (2),

extinction/backscatter ratio (4) at 4 wavelengths $(441,673,873,1022 \mathrm{~nm})$ of AERONET. The number in the parentheses indicates the number of variables.

\section{Identification of column-integrated dominant aerosols}

Y. Choi et al.

\section{Title Page}

Abstract

Introduction

Conclusions

References

Tables

Figures

14

DI

4

Back

$\checkmark$

Close

Full Screen / Esc

Printer-friendly Version

Interactive Discussion 


\section{ACPD}

13, 26627-26656, 2013

\section{Identification of} column-integrated dominant aerosols

Y. Choi et al.

Table 2. Optical properties of dominant aerosols (mean \pm standard deviation).

\begin{tabular}{lccccc}
\hline Aerosol Type & $\mathrm{AOD}_{440}$ & $\mathrm{SSA}_{440}$ & $\mathrm{AAE}_{440-1020}$ & $\mathrm{FMF}$ & Fraction $^{*}$ \\
\hline $\mathrm{MD}$ & $2.30 \pm 0.15$ & $0.92 \pm 0.00$ & $2.81 \pm 0.01$ & $0.08 \pm 0.01$ & $0.6 \%$ \\
MD + Carbon & $0.83 \pm 0.34$ & $0.92 \pm 0.03$ & $1.82 \pm 0.34$ & $0.22 \pm 0.13$ & $10.9 \%$ \\
Mixed Coarse & $0.61 \pm 0.20$ & $0.91 \pm 0.03$ & $1.14 \pm 0.21$ & $0.33 \pm 0.12$ & $43.7 \%$ \\
$\mathrm{BC}$ & $0.65 \pm 0.18$ & $0.90 \pm 0.03$ & $1.08 \pm 0.11$ & $0.64 \pm 0.10$ & $15.7 \%$ \\
OC & $0.64 \pm 0.22$ & $0.91 \pm 0.02$ & $1.47 \pm 0.15$ & $0.65 \pm 0.10$ & $11.1 \%$ \\
Secondary ions & $0.76 \pm 0.35$ & $0.97 \pm 0.01$ & $1.30 \pm 0.25$ & $0.79 \pm 0.10$ & $18.0 \%$ \\
\hline
\end{tabular}

Title Page

Among dominant aerosols.

14

4

\section{Full Screen / Esc}

Printer-friendly Version

Interactive Discussion 


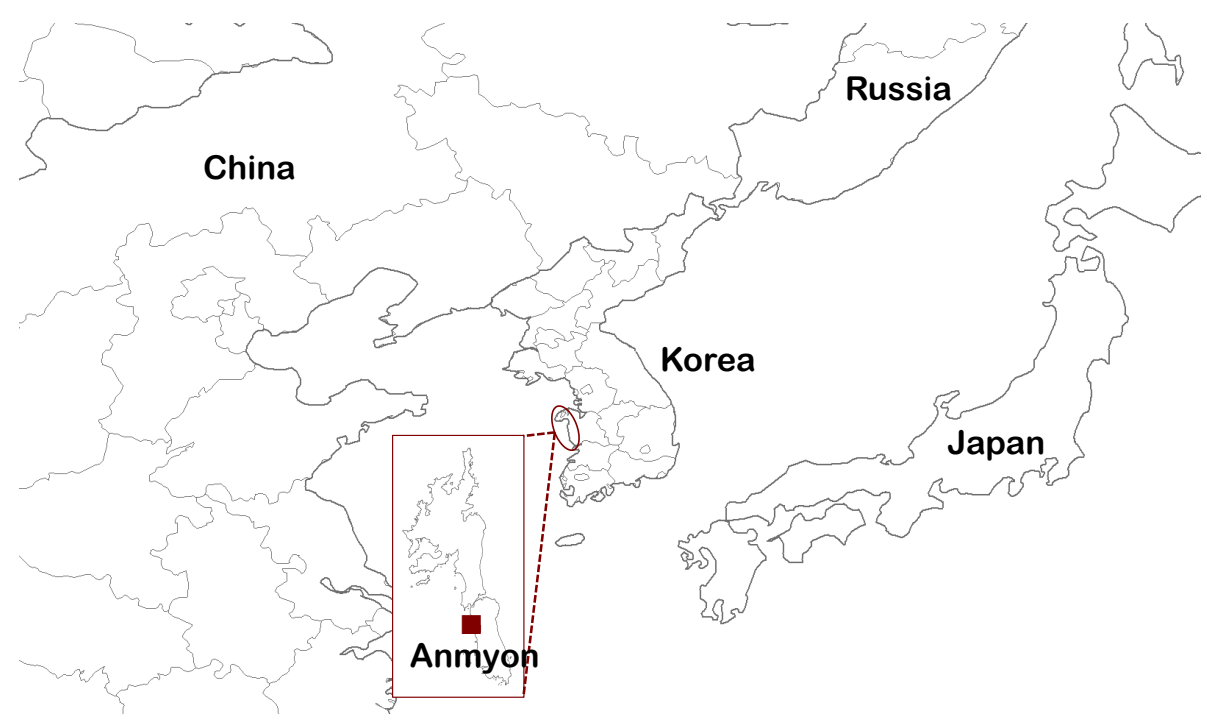

\section{ACPD}

13, 26627-26656, 2013

Identification of column-integrated dominant aerosols

Y. Choi et al.

Title Page

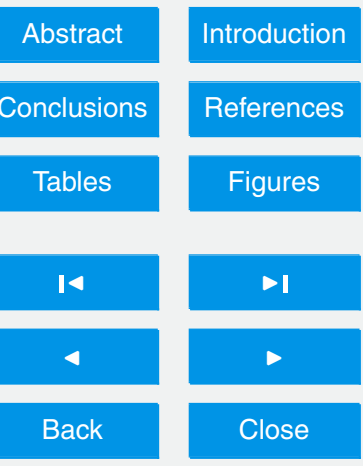

Full Screen / Esc

Printer-friendly Version

Interactive Discussion 


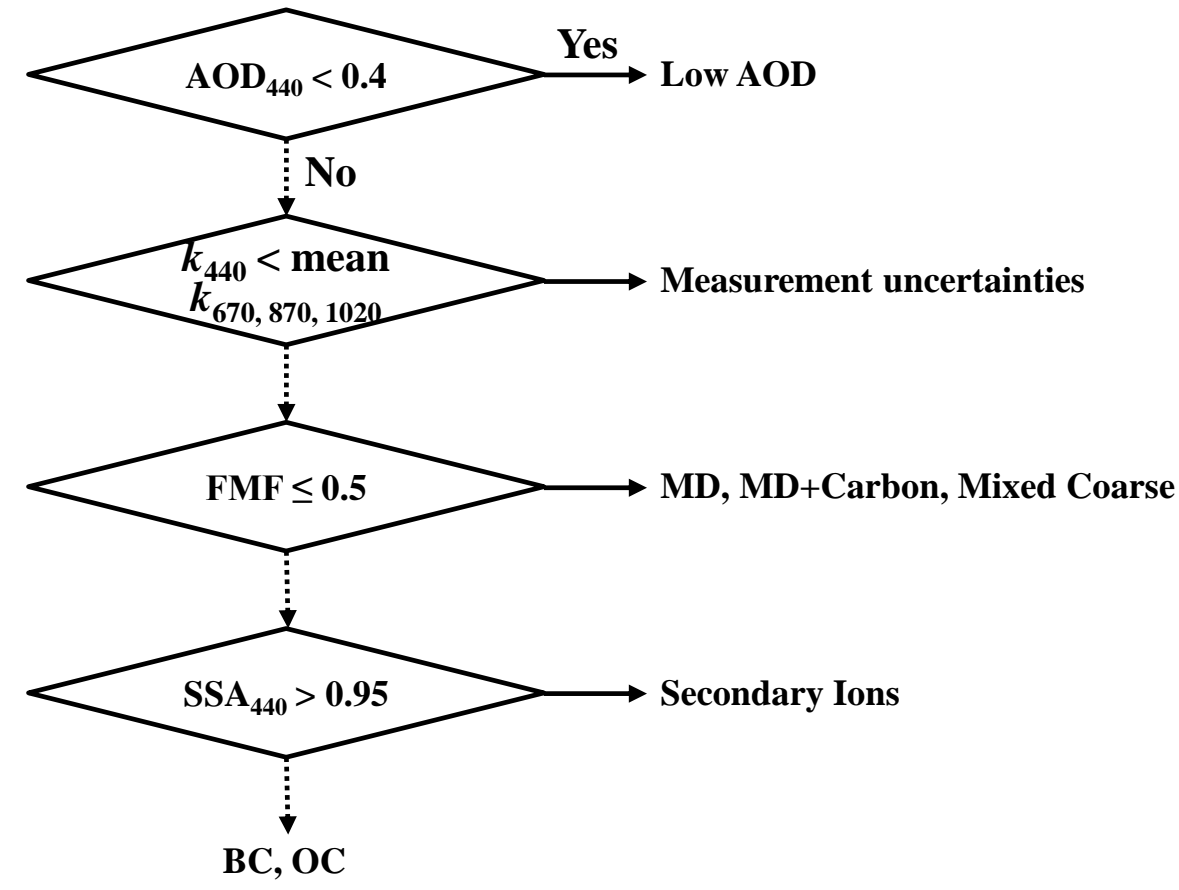

\section{ACPD}

13, 26627-26656, 2013

\section{Identification of column-integrated dominant aerosols}

Y. Choi et al.

Title Page

\section{Full Screen / Esc}

Fig. 2. Classification of dominant aerosol types. MD, MD+Carbon, and Mixed Coarse from the coarse mode and $B C$ and $O C$ from the fine mode are further classified by a clustering method using $\mathrm{AOD}_{440}, \mathrm{SSA}_{440}, \mathrm{AAE}_{440-1020}$ and FMF. See the text for details.

Printer-friendly Version

Interactive Discussion 


\section{ACPD}

13, 26627-26656, 2013

Identification of column-integrated dominant aerosols

Y. Choi et al.
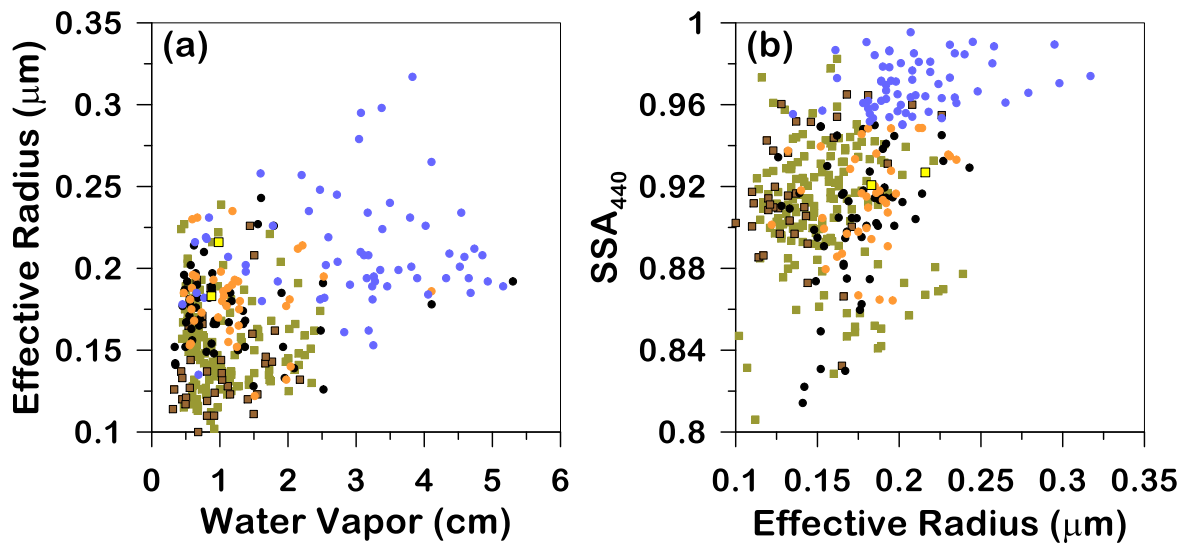

Title Page
Abstract

Conclusions

Tables

14

4

Back

Introduction

References

Figures

DI

$>$

Close

Fig. 3. Scatter plots of (a) effective radius of the fine-mode dominant aerosols vs. column water vapor and (b) $\mathrm{SSA}_{440}$ vs. effective radius of the fine-mode dominant aerosols.

Printer-friendly Version

Interactive Discussion 
(a)
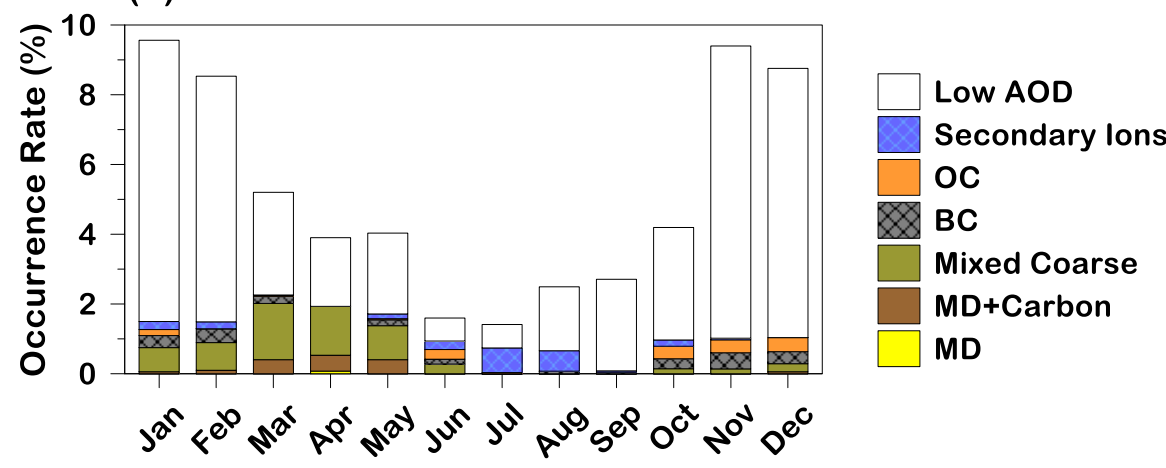

(b)

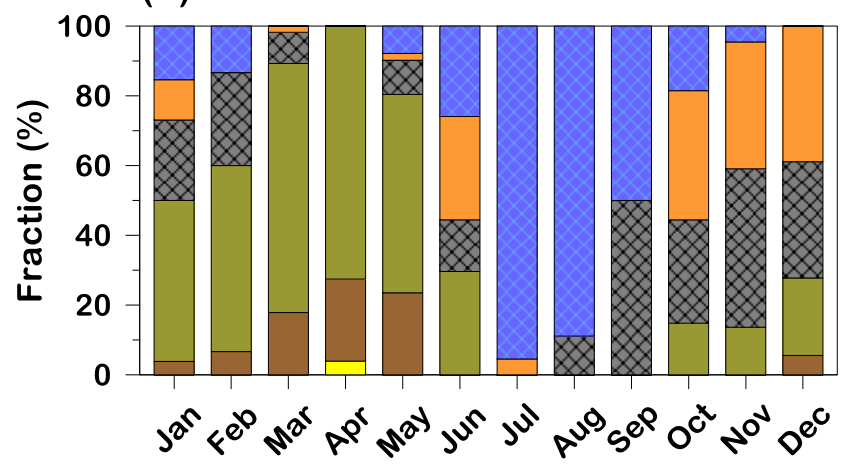

Fig. 4. Monthly variations in (a) the occurrence rates of dominant aerosols along with aerosols of low AOD and (b) the fractions of each aerosol type among dominant aerosols. Low AOD denotes aerosols with $A O D<0.4$. Dominant aerosols were identified excluding low AOD aerosols.

\section{ACPD}

\section{3, 26627-26656, 2013}

\section{Identification of column-integrated dominant aerosols}

Y. Choi et al.

Title Page

\section{Full Screen / Esc}

Printer-friendly Version

Interactive Discussion 
(a)

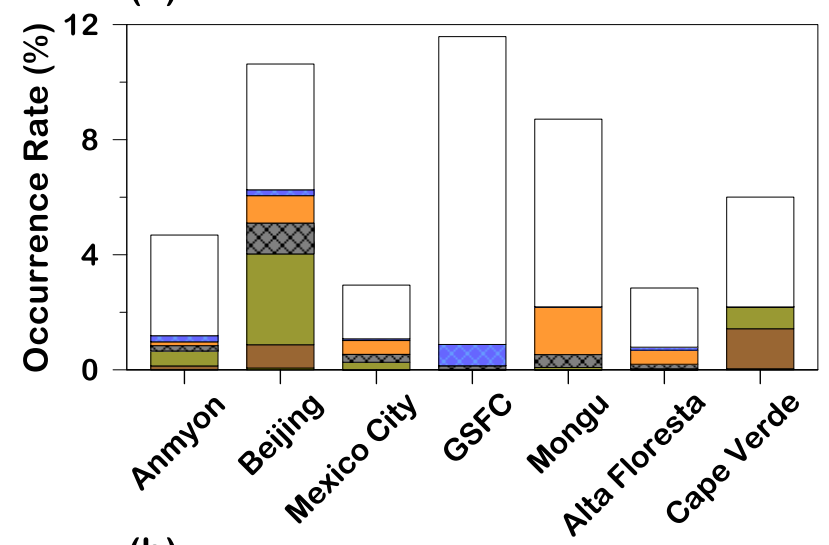

(b)

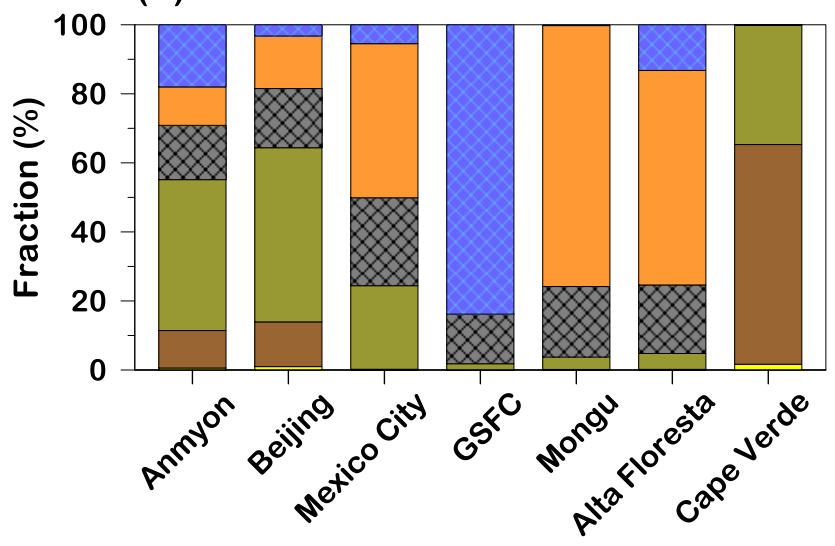

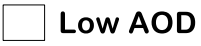

Secondary Ions

OC

BC

Mixed Coarse

MD+Carbon

MD

\section{ACPD}

\section{3, 26627-26656, 2013}

\section{Identification of}

column-integrated dominant aerosols

Y. Choi et al.

\section{Title Page}

\section{Full Screen / Esc}

Printer-friendly Version

Interactive Discussion the fractions of each aerosol type among dominant aerosols at selected AERONET sites in comparison with those of the Anmyon site. 

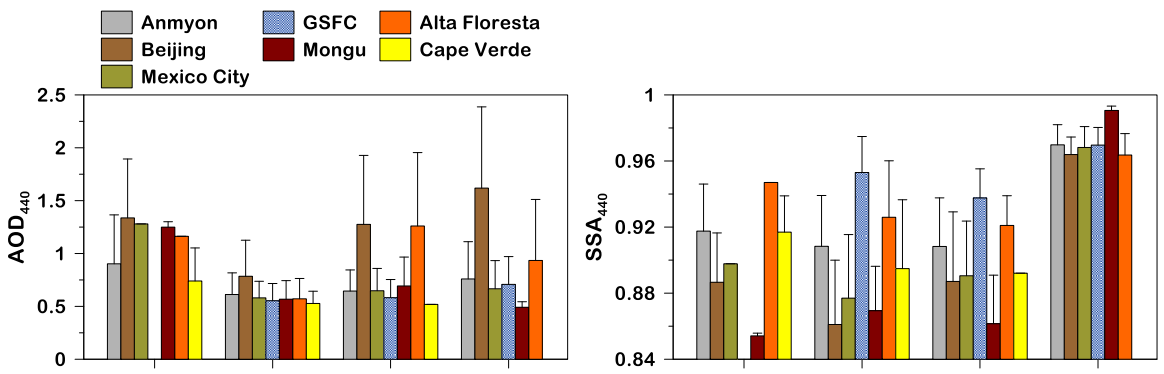

ACPD

13, 26627-26656, 2013

Identification of column-integrated dominant aerosols

Y. Choi et al.
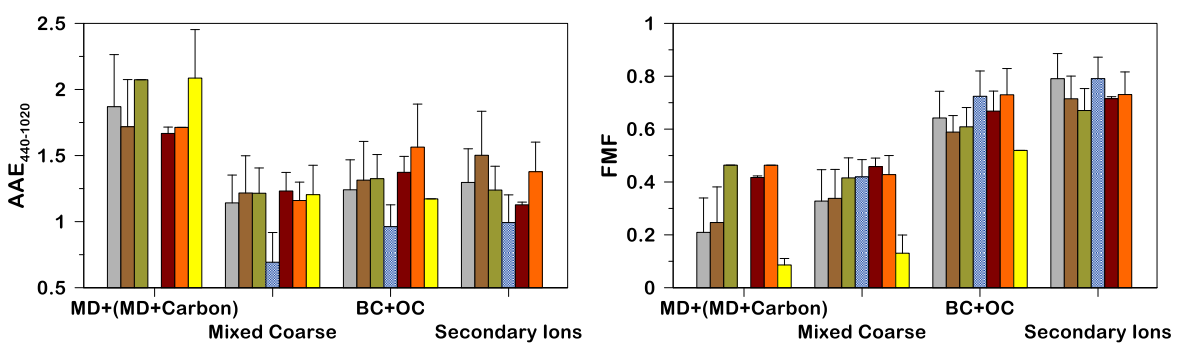

Title Page

Fig. 6. Mean optical properties of major categories of dominant aerosols by AERONET site. Error bars above bar graphs indicate the standard deviation.

\section{Full Screen / Esc}

Printer-friendly Version

Interactive Discussion 